\title{
Subulina octona (Bruguière, 1798) - a new greenhouse species for the Czech Republic (Mollusca: Gastropoda: Subulinidae)
}

\author{
LUCIE JUŘIČKOVÁ
}

Department of Zoology, Charles University, Viničná 7, CZ-12844 Praha 2, Czech Republic, e-mail: lucie.jurickova@seznam.cz

\begin{abstract}
JUŘIČKOVÁ L., 2006: Subulina octona (Bruguière, 1798) - a new greenhouse species for the Czech Republic (Mollusca: Gastropoda: Subulinidae). - Malacologica Bohemoslovaca, 5: 1-2. Online serial at $<$ http://mollusca.sav.sk> 30-Jan-2006.
\end{abstract}

\begin{abstract}
The occurrence of land snail Subulina octona (Bruguière 1798) (Gastropoda: Subulinidae) is reported from the Czech Republic greenhouse for the first time. Molluscan communities of two new Bohemian greenhouses are characterized.
\end{abstract}

\section{Introduction}

Subulina octona (Bruguière 1798) is a tropical snail, which naturally occurs in the Caribbean (DEISLER \& ABBOTT 1984) and in tropical America (PILSBRY 1946, DuNDEE 1974) where it is locally common. This species has been introduced worldwide in the tropics (AвBOtT 1989, Deisler \& ABbotT 1984, DundeE 1974, PILSBRY 1946). S. octona occurs in ground litter of moist places in tropical and subtropical forests, but it also occurs in open habitats (ALVAREZ \& WILLIG 1993) and, in Nothern America and Europe (Britain, Ireland, Denmark and Germany), in greenhouses and hothouses. It feeds mostly on plant materials and debris. This species serves as an intermediate host for the trematode Postharmostomum gallinum, which infects domestic chickens and for the nematode $\mathrm{An}$ giostrongylus cantonensis (DE FARIA DUARTE 1980, DE ALMEIDA BESSA et al. 2000).

\section{Description of species}

S. octona is $14-17 \mathrm{~mm}$ heigh, shell is narrow and tapering, straight-sided, with 9-11 convex whorls parted by a deep suture. The aperture is small and ovate, outer lip sharp and simple; base of columella slightly but distinctly truncate. Shell is thin, colorless or yellowishcorneous, glossy and translucent, growth-lines fairly well-marked, especially on the last whorl. Animal is yellow. A similar greenhouse species, which occurred in Africa originally Subulina striatella (Rang 1831) is larger $(16-24 \mathrm{~mm})$, shell is superficial rather like $S$. octona with flatter-sided, less tumid whorls and with much stronger and more regular growth-ridges, giving a finely ribbed effect. Shell is also less glossy (Fig. 1). Many reputed occurrences require confirmation, as both these species have several times been recorded in error for other species of Subulinidae (KERNEY et al. 1983, PILSBRY 1946).

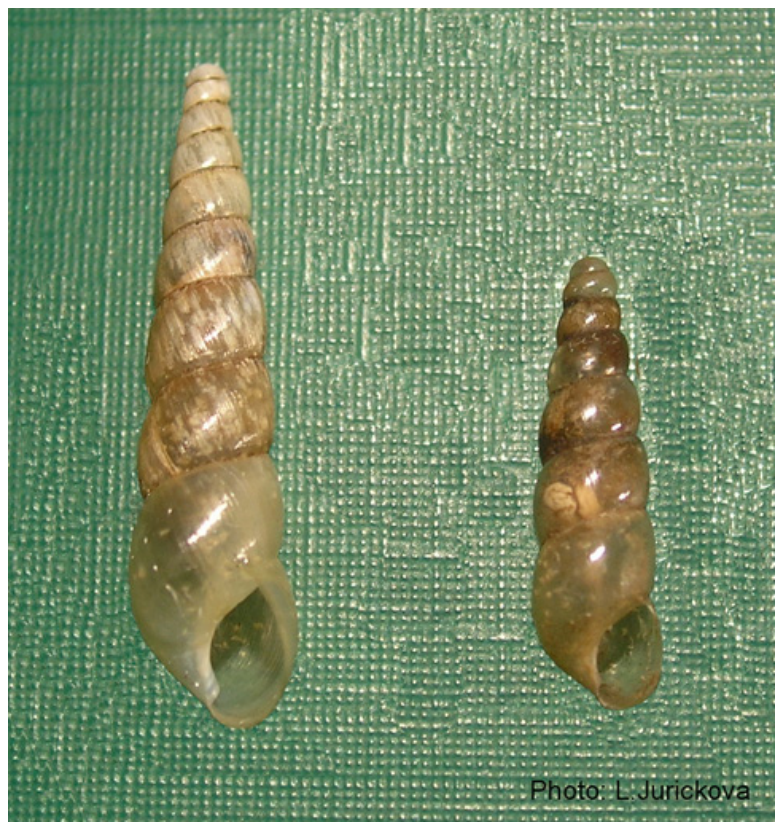

Fig. 1. Subulina octona (Bruguière 1798) - Fata Morgana greenhouse Prague 2005 (right) and Subulina striatella (Rang 1831) Kew Garden London 2004 (left). Photos L. Juřičková. 
The actual list of species whose occurrence is restricted to greenhouses in the Czech Republic does not include any species of genus Subulina (HORSÁK et al. 2004).

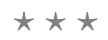

\section{Localities and method}

Land and freshwater snails of two new tropical greenhouses Fata Morgana in Prague (opened 2003) and Liberec Botanical Gardens (opened in 2000) were studied by hand picking. Both sites were studied in 2005.

\section{Results and discussion}

Altogether 12 species of gastropods were recorded in two newly constructed greenhouses in the Czech Republic (5 species in Fata Morgana and 7 species in Liberec Botanical Gardens) (see Table 1). The molluscs were introduced with plants to these greenhouses during two and five years respectively. Two species were recorded in the Czech Republic greenhouses for the first time. Oxyloma elegans occurs in the outskirts of Prague, but Subulina octona was recorded for the first time. This population may probably spread faster than other species due to self-fertilization (DE AlMEIDA BESSA \& DE BARRos ARAUJo 1996).

Table 1. The molluscan assemblages in two localities under study.

\begin{tabular}{lcc}
\hline List of species & Fata Morgana & Liberec Botanical Gardens \\
\hline Melanoides tuberculata & & 1 \\
Carychium minimum & & 2 \\
Discus rotundatus f. pyramidalis & & 4 \\
Lucilla syngleiana & & 2 \\
Hawaia minuscula & 10 & \\
Subulina octona & 10 & 3 \\
Lamellaxis clavulinus & & \\
Lehmannia marginata & 3 & \\
Oxyloma elegans & 1 & \\
Euconulus fulvus & 3 & \\
Zonitoides nitidus & & \\
Oxychilus draparnaudi & & \\
\hline
\end{tabular}

Acknowledgement: The research reported here was supported by MŠMT project 0021620828 .

\section{References}

Alvarez J. \& Willig M.R., 1993: Effects of treefall gaps on the density of land snails in the Luquillo experimental forest of Puerto-Rico. - Biotropica, 25(1): 100-110.

De Almeida Bessa E.C. \& De Barros Araujo J.L., 1996: Ocorrencia de autofecundacao em Subulina octona (Bruguiere) (Pulmonata, Subulinidae) sob condicoes de laboratorio [Ooccurrence of self-fertilization in Subulina octona (Bruguiere) (Pulmonata, Subulinidae) under laboratorial conditions]. - Revista Brasileira de Zoologia, 12(3): 719-723.

de Almeida Bessa E.C., dos Santos Lima W., Daemon, Cury M.C. \& DE Barros ARAujo J.L., 2000: Desenvolvimento biologico de Angiostrongylus vasorum (Baillet) Kamensnky (Nematoda, Angiostrongylidae) em Subulina octona Bruguiere (Molusca, Subulinidae) em condicoes de laboratorio [Biological development of Angiostrongylus vasorum (Baillet) Kamensky (Nematoda, Metastrongylidae) in Subulina octona Bruguiere (Mollusca, Subulinidae) in laboratory conditions]. - Revista Brasileria de Zoologica, 17(1): 29-41.
DeISLER J.E. \& ABBotT R.T., 1984: Range extensions of some introduced land molluscs in the Bahama Islands, with first reports for four species. - The Nautilus, 98(1): $12-17$.

DunDEE D.S., 1974: Catalog of introduced molluscs of eastern North America (North of Mexico). - Sterkiana, 55: $1-37$.

HoRSÁK M., DVOŘÁK L. \& JUŘIČKOVÁ L., 2004: Greenhouse gastropods of the Czech Republic: current stage of research. - Malacological Newsletter, 22: 141-147.

PILSBRY H.A., 1946: Land Mollusca of North America (North of Mexico). Vol. II. Part 1. - The Academy of Natural Sciences of Philadelphia, Monographs No. 3, $520 \mathrm{pp}$. 